\title{
Soluble Immune Complexes in Patients with Diabetes Mellitus: Detection and Pathological Significance
}

\author{
G. Virella ${ }^{1}$, H. Wohltmann ${ }^{2}$, J. Sagel ${ }^{3}$, M. F. L. Lopes-Virella ${ }^{3}$, M. Kilpatrick ${ }^{1}$, C. Phillips ${ }^{1}$, and J. Colwell ${ }^{3}$ \\ Department of Basic and Clinical Immunology and Microbiology ${ }^{1}$, Department of Pediatrics ${ }^{2}$, \\ and Veterans Administration Medical Center ${ }^{3}$ and Endocrinology-Metabolism-Nutrition Division, Department of Medicine, \\ Medical University of South Carolina, Charleston, USA
}

Summary. A series of 148 diabetic patients were studied for the presence of soluble immune complexes using five different screening techniques. The percentage of positive results was $26 \%$ with direct nephelometry and PEG-C4, 27\% with PEG-IgG, $33 \%$ with radiolabelled Clq binding and $57 \%$ with a specific technique for detection of insulin-anti-insulin immune complexes. The percentages of positivity in a group of 40 healthy donors were $2.5 \%$ for direct nephelometry and radiolabelled $\mathrm{Clq}$ binding, $5 \%$ for the PEG-C4 technique, and $10 \%$ for the PEG-IgG technique. Sixteen percent of the patients studied had positive results in three or more of the screening tests. When the results of the different screening tests in all patients and controls were compared among themselves, we found correlation coefficients between $-0.01(p=0.854)$ when the direct nephelometry and the PEG-C4 tests were compared and $0.29(p<0.0003)$ when the direct nephelometry and PEG-IgG tests were compared. When the results of each test for the whole group of patients and the group of normal healthy donors were compared, significant differences were found for direct nephelometry ( $p=0.004)$, PEG-IgG, PEG-C4, and insulin-anti-insulin immune complexes $(p<0.0001)$, as well as for anti-insulin antibodies $(p<0.001)$; no significant difference was observed when the results of radiolabelled $\mathrm{Clq}$ binding in diabetics and controls were compared $(p=0.2)$. Significant correlations were found between the results of several screening tests for soluble immune complexes, insulin dosage, and clinical or biochemical expressions of microangiopathy, nephropathy, or vasculopathy. These correlations were more consistent when we divided the patients into normal or abnormal groups for proteinuria, microangiopathy, and diabetic complications and considered the number of positive tests in each patient rather than the results of individual tests.
Key words: Immune complexes, anti-insulin antibodies, diabetes mellitus, nephropathy, peripheral neuropathy, diabetic complications.

The possibility that soluble immune complexes (IC) involving insulin and anti-insulin, as well as other antigen-antibody systems, play some role in the pathogenesis of the complications of diabetes mellitus was first postulated by Faulk et al. [6]. Subsequent investigations using different screening techniques demonstrated the presence of soluble IC in the sera of diabetic patients. Jayarao et al. in 1973 [15] reported the presence of insulin-anti-insulin IC in the sera of insulin-resistant diabetics. More recently, Kumar and Quismorio using a Clq binding assay found an overall incidence of $29 \%$ of positive results, with a maximum of $71 \%$ in insulin-resistant patients $[17,18]$. Schernthaner et al. [26] using the same technique found an overall positive result of $23 \%$, but higher frequencies in patients with low anti-insulin antibody titers, onset at ages older than 15 years, and long duration of disease. Irvine et al. [13] reported an increase in IC as measured by a solid phase $\mathrm{Clq}$ binding assay in patients with diabetic retinopathy.

The involvement of antigen-antibody systems other than insulin-anti-insulin was first suggested by Irvine et al. [11, 12], who found positive results using nonspecific screening techniques in a group of newly diagnosed insulin-dependent diabetics, with a significant correlation between IC and the presence of islet cell antibodies. This was confirmed by Delespesse et al. [4].

We have carried out a comparative study of different screening techniques for soluble immune complexes in a large series of patients, combining an anti- 
gen-specific technique with four nonspecific techniques in order to determine which test (or combination of tests) will best identify those patients with elevated levels. The study was also designed to examine the relationship between immune complexes and diabetic complications suggested by previous investigators $[6,13]$.

\section{Patients and Methods}

\section{Patients}

One hundred and forty-eight patients were included in the present study, divided into the following groups:

I. Non-obese, ketosis-prone, insulin-dependent diabetics. This group included 74 patients, with a mean age of 15 years (range $4-55$ years), and mean percent body weight of $+7.2 \%$ (range -16 to $+23 \%$ ).

II. Non-obese, non-ketosis prone diabetics. Thirty-four patients were included in this group with a mean age of 44 years (range $18-58$ years) and mean percent body weight of $+7 \%$ (range -17 to $+20 \%)$. Ten patients $(29 \%)$ were studied at the time of diagnosis; the mean duration of disease in the remaining patients was 11.5 years (range 3 months to 29 years). The large majority of patients $(82 \%)$ were treated with insulin (mean daily dosage $0.76 \mathrm{U} / \mathrm{kg}$ ); the remaining were treated exclusively with sulphonylureas.

III. Obese, insulin-independent diabetics. Twenty-eight patients were included in this group with a mean age of 49 years (range $18-58$ years) and mean percent body weight of $+41 \%$ (range +22 to $+106 \%$ ). Five patients were studied at the time of diagnosis. The mean duration of disease in the remaining patients was 6.5 years (range 2 months to 20 years). Fifty-four percent of the patients in this group were treated with insulin. The remainder were treated with diet and/or sulphonylureas.

IV. Patients with impaired glucose tolerance. This group included four individuals with a mean age of 46 years (range 31-63 years) and mean percent body weight of $+10 \%$ (range -19 to $+25 \%$ ).

$V$. Patients with secondary diabetes. This group included eight patients with chronic pancreatitis, three of them having been submitted to partial pancreatectomy. Their mean age was 41 years (range 24-63 years) and the mean percent body weight in this group was $-14 \%$ (range -30 to $+11 \%$ ).

For some specific comparisons, the patients were rearranged in groups according to: a) duration of disease, b) dosage of insulin, c) therapy with insulin or oral anti-diabetic agents, d) degree of control, e) abnormal proteinuria, and f) clinical evidence of retinopathy, peripheral neuropathy, peripheral vasculopathy, and nephropathy.

Retinopathy and peripheral neuropathy were evaluated in all patients included in the study by a careful routine physical, ophthalmological, and neurological examination. Questionable abnormalities were further evaluated by ophthalmological consultation and nerve conduction studies. Peripheral macrovascular disease was evaluated by a history of intermittent claudication and observation of trophic or ischaemic phenomena, and nephropathy was evaluated clinically by determining creatinine clearance and proteinuria by a dip-stick technique (Multistick, Ames, Elkhart,
Indiana). In this series, 22 patients had typical diabetic retinopathy, 19 had peripheral neuropathy, 11 had peripheral vascular disease, and 8 had nephropathy by the criteria outlined above.

Forty-seven patients of our group I were classified as being in good metabolic control when they excreted less than $5 \%$ of total dietary available glucose in the $24 \mathrm{~h}$ urine (range $0.8-9.6 \mathrm{~g} / 24 \mathrm{~h}$ ) and $\mathrm{HbA}_{1 \mathrm{c}}$ was below $10 \%$, fair control defined by $\mathrm{HbA}_{1 \mathrm{c}}$ levels between 10 and $13 \%$ and urinary glucose excretion between 5 and $10 \%$ of total available dietary glucose (range 13-24.5 g/24 h), or poor control (when the excretion of urinary glucose exceeded $10 \%$ of total dietary glucose (range $42-110 \mathrm{~g} / 24 \mathrm{~h}$ ) and $\mathrm{HbA}_{1 \mathrm{c}}$ exceeded $13 \%$ ).

All the serum samples were obtained from blood collected by venipuncture after overnight fasting when possible. Blood was collected either before the morning insulin or at least $4 \mathrm{~h}$ after the previous insulin administration. The serum was aliquoted immediately after separation and either tested in the following $72 \mathrm{~h}$ or frozen at $-70^{\circ} \mathrm{C}$ until further use. Twenty-four-hour urine samples were obtained from 85 patients.

\section{Measurement of Soluble Immune Complexes (IC)}

a. Direct Nephelometry. The method described previously [31] was used with slight modifications. In order to standardise the readings, the nephelometer used (Hyland PDQ Nephelometer, Hyland Diagnostics, Banackburn, Illinois) was always set to the same sensitivity (coarse -3 , fine -6 ); at these settings, the final adjustment was made with a latex suspension $(10 \mu \mathrm{l}$ of a suspension of polystyrene latex particles of $0.035 \mu \mathrm{m}$ diameter (Dow Diagnostics, Indianapolis, Indiana) in $10 \mathrm{ml}$ of $3 \%(\mathrm{w} / \mathrm{v})$ polyethylene glycol 6000 (PEG) in saline. With this suspension, the fine sensitivity was adjusted to provide a reading between 170-190. The final value read with the latex suspension after subtraction of all blanks was considered as $100 \%$ and the results for serum samples were expressed as a percentage of the reading of the latex suspension. To avoid spurious values due to lipids, all determinations where the blank sample (sample diluted in $0.154 \mathrm{~mol} / 1$ saline) read over $10 \%$ of the value determined for the reference latex suspension were omitted. The mean value for 108 samples from 55 normal healthy donors was $2.3 \%$ (range $0-10 \%$ ).

b. PEG-C4 and PEG.IgG Tests. These methods were modifications of those originally proposed by Digeon et al. [5]. The samples were incubated with $3 \%(\mathrm{w} / \mathrm{v})$ PEG (fresh solutions prepared weekly) overnight at $4{ }^{\circ} \mathrm{C}$; the precipitates were washed twice in ice-cold 3\% PEG and resuspended in borate buffer $0.1 \mathrm{~mol} / \mathrm{l}$, (pH 8.4) containing $0.4 \%$ Tween $20(\mathrm{v} / \mathrm{v})$; samples were incubated at $37^{\circ} \mathrm{C}$ for $30-60 \mathrm{~min}$ to enhance solubilisation. Finally, IgG and $\mathrm{C} 4$ were assayed nephelometrically in both the original serum and the resuspended precipitates, and the results of the test were expressed as the following ratio:

$$
\frac{\text { IgG or } C 4 \text { concentration in precipitate }}{\text { IgG or } C 4 \text { concentration in serum }} \times 100
$$

The mean and standard deviation values for these two techniques in 120 serum samples collected from 55 normal healthy controls were $17 \pm 8 \%$ for the PEG-C4 test and $0.2 \%$ $\pm 0.1 \%$ ) for the PEG-IgG test.

c. Radiolabelled Clq test. The method of Zubler et al. [33] was used without modifications. The mean $\mathrm{Clq}$ binding value for the sera of 37 normal healthy donors was $6.03 \%$ (range $3.6-7.3 \%$ ).

d. Assay of Insulin-anti-insulin IC. A modification of the test of Jayarao et al. [15] was used. An aliquot of serum was dialysed 
overnight against glycine- $\mathrm{HCl}$ buffer $0.15 \mathrm{~mol} / 1$ (pH 3.0), to dissociate possible immune complexes [32]. Dextran-coated charcoal, prepared by mixing $0.5 \mathrm{~g}$ of dextran T-70 (Pharmacia Fine Chemicals, Piscataway, New Jersey) and $5 \mathrm{~g}$ of activated charcoal (Sigma Chemicals, St. Louis) with $100 \mathrm{ml}$ of the same acid buffer, was then added to the sample. After $30 \mathrm{~min}$ incubation, the sample was centrifuged at $800 \mathrm{~g}$ for $15 \mathrm{~min}$, the total volume was noted, and the supernatant saved and neutralised by dialysis against barbitalbuffered saline, $\mathrm{pH}$ 7.4. An untreated sample was diluted to the same extent, and both samples were then used for the assay of radiolabelled insulin binding (see below). If soluble IC were present, an increased binding activity of the treated sample would be expected. The results were expressed as the difference of the binding capacities between acidified and untreated samples. The mean and standard deviation obtained from a group of 40 sera from 30 normal healthy donors were $4.1 \pm 2.1 \%$.

\section{Assay of Anti-Insulin Antibodies}

The coated charcoal immunoassay for insulin reported by Herbert et al. [10] was used with some modifications [31]. Insulin labelled with ${ }^{125}$ Iodine was obtained from Corning Medical, Medfield, Massachusetts (approximate specific activity $0.103 \mathrm{Ci} / \mathrm{mol}$ of insulin), and after dilution to the appropriate activity it was added to 1:5 dilutions of the sera tested (previous trials showed this dilution to be associated with maximal binding). After incubation for $2 \mathrm{~h}$ at $37^{\circ} \mathrm{C}$, dextran-coated charcoal was added to adsorb free insulin, and the radioactivity in the pellet and supernatant was counted. The results were expressed as the following ratio:

$\underline{\text { radioactivity in the pellet }- \text { radioactivity in the supernatant }} \times 100$

When 40 sera from 30 normal donors were treated in this way, we obtained a mean ratio of $78 \%$ (range: $70-89 \%$ ).

\section{Haemoglobin $A_{\text {Ic }}$ levels}

$\mathrm{HbA}_{1 \mathrm{c}}$ was measured in all patients by isoelectric focussing of erythrocyte haemolysates over a $\mathrm{pH}$ gradient of $6-8$, according to the method of Spicer et al. [28]. $\mathrm{HbA}_{1 \mathrm{c}}$ was expressed as a percentage of the total haemoglobin.

\section{Urine Studies}

The urines collected from 85 of the patients included in this study were analysed quantitatively and qualitatively.

Assay of Total Proteins. Total proteins were determined in unconcentrated urine using the Bio-Rad protein assay system, a colorimetric method of high sensitivity, with a detection limit of $170 \mathrm{mg} / \mathrm{l}$. In patients with marked polyuria, the assay was performed using dilute reagent (1:6 in distilled water), dilute standards $(6.25-100 \mu \mathrm{g} / \mathrm{ml})$, and a larger sample: reagent ratio $(0.8 \mathrm{ml}$ of sample added to $1.2 \mathrm{ml}$ of diluted dye solution). In a group of 32 normal controls, mean $24 \mathrm{~h}$ proteinuria was $129 \pm 42 \mathrm{mg}$.

Assay of Urinary Albumin. Urinary albumin was quantitated by laser nephelometry [3], using reagents supplied by Hyland Diagnostics, Banackburn, Illinois. The mean excretion of albumin $/ 24 \mathrm{~h}$ in 23 individuals with normal values for total proteinuria and electrophoretic separations compatible with normal kidney function was $4.2 \mathrm{mg} / 24 \mathrm{~h}$ (range $0-11.7 \mathrm{mg} / 24 \mathrm{~h}$ ).

Assay of Urinary Beta $_{2}$-Microglobulin. This assay was performed using the Phadebas beta - $_{2}$-microglobulin radioimmunoassay (Phar- macia Diagnostics, Piscataway, New Jersey). The mean beta 2 -microglobulin excretion in 36 healthy controls was $26 \mu \mathrm{g} / 1$ (range $0-93 \mu \mathrm{g} / \mathrm{l})$.

Analytical Characterisation of Proteinuria by Sodium Dodecyl Sulphate - Polyacrylamide Gel (SDS-PAGE). The technique outlined by Pires et al. [25] was used with the modifications introduced by Lopes-Virella et al. [21]. The interpretation of the electrophoretic patterns as normal or abnormal was made blindly by two independent observers.

\section{Limits of Normality}

The limits of normality for the results of IC screening tests and quantitative urinary studies were set according to whether the results on the population of normal healthy donors followed or not a normal distribution. In the affirmative case (PEG-IgG, PEG-C4, insulin anti-insulin IC and total proteinuria), the mean +2 SD was established as maximum limit of normality, values exceeding this value being considered positive or abnormal. In the case of the PEG-IgG and PEG-C4 tests, values greater than the mean +1 SD and smaller or equal to the mean +2 SD were considered borderline. When the distribution of the control population was significantly skewed (direct nephelometry, Clq binding, anti-insulin antibody, albuminuria, beta ${ }_{2}$-microglobulinuria) we used the 95th percentile to define the upper level of normality [22]. In the case of direct nephelometry and $\mathrm{Clq}$ binding test, values greater than the 68 th percentile and smaller or equal to the 95 th percentile were considered borderline.

\section{Statistical Analysis of Results}

A combination of statistical tests was used in our data analysis. Most variables followed a non-parametric distribution in the control and/or in the patient populations, and we used non-parametric tests. In the case of the PEG-C4 test, both control and patient populations followed a normal distribution, so that parametric tests were used in comparisons involving the results of this test. Combinations of two continuous variables were compared either by analysis of variance and Duncan's multiple range test, or by the Kruskal-Wallis distribution-free multiple comparison test when multiple groups were involved; Student's t test or Spearman's rank correlation coefficient (Spearman's rho) test were used when only two groups were compared. Combinations of continuous and discrete variables were compared by Student's t test or by the MannWhitney test.

\section{Results}

\section{Analysis of the Results Obtained with Screening Methods for Soluble IC}

With the exception of the radiolabelled Clq binding test, all other screening tests for soluble IC, and the assay for free anti-insulin antibodies, showed significantly different results between the group of diabetic patients and the group of normal controls $(p<0.001$ in all cases).

The results of IC screening tests and anti-insulin antibodies in the whole group of diabetics are shown in Table 1. The percentage of positive results varied between a maximum of $57 \%$ for insulin-anti-insulin 
Table 1. Immune complex screening with five different techniques in 148 diabetic patients

\begin{tabular}{lccccc}
\hline & $\begin{array}{l}\text { Direct } \\
\text { nephelo- } \\
\text { metry }\end{array}$ & PEG-C4 & PEG-IgG & $\begin{array}{l}\text { Clq } \\
\text { binding }\end{array}$ & $\begin{array}{l}\text { Insulin-anti- } \\
\text { insulin IC }\end{array}$ \\
\hline No. of patients & 110 & 143 & 148 & 127 & 139 \\
Positive & $29(25 \%)$ & $33(26 \%)$ & $40(27 \%)$ & $42(33 \%)$ & $75(57 \%)$ \\
Borderline & $10(9 \%)$ & $36(24 \%)$ & $25(17 \%)$ & $9(7 \%)$ & $22(17 \%)$ \\
Negative & $71(65 \%)$ & $74(50 \%)$ & $83(56 \%)$ & $76(60 \%)$ & $35(26 \%)$ \\
\hline
\end{tabular}

IC to $26 \%$, using direct nephelometry and the PEG$\mathrm{C} 4$ technique.

The results obtained with these different screening methods were compared to determine the agreement between methods. The best correlation coefficient was observed comparing direct nephelometry with PEG-IgG $(r=0.29 ; p<0.0003)$. A stronger correlation was seen between the levels of anti-insulin antibodies and insulin-anti-insulin IC ( $r=0.54$; $p<0.0001$ ). The results were also divided into two groups, positive or negative, according to the criteria expressed in the Patients and Methods section, and the techniques were compared two-by-two for the agreement between results obtained with the same sera. The best agreements (71.7 and $70.3 \%$ ) were observed comparing direct nephelometry with the PEG-IgG and the radiolabelled Clq binding techniques. The poorest agreements were observed when insulin-anti-insulin IC were compared with the nonspecific techniques, ranging from an agreement of 45.3\% when compared with the PEG-IgG technique to $57 \%$ when compared with the radiolabelled Clq binding assay. To obtain a general index of the behaviour of each serum in our IC screening tests, we determined the number of positive results for each serum. Sixteen percent of our total population of diabetics had three or more positive results in the five screening tests run.

When two large groups of patients were separated from our population, according to whether or not they had been treated with insulin previously to the collection of serum for IC studies, we verified that there was statistically no significant difference between the results of the four nonspecific tests, while insulin-anti-insulin IC and anti-insulin antibodies were significantly higher in insulin-treated patients (Table 2).

\section{Analysis of Possible Correlations Between IC Screening and Other Clinical and Biochemical Data}

The following clinical and biochemical data were compared with the results of IC screening tests: type of diabetes, insulin treatment, duration of treatment with insulin, dosage of insulin (U/day and $\mathrm{Ukg}^{-1}$ day $^{-1}$ ), duration of disease, clinical evidence of nephropathy, neuropathy, retinopathy, or peripheral macrovascular disease, clinical "control", proteinuria, albuminuria, urinary beta ${ }_{2}$-microglobulin, SDS-PAGE of urine, and free anti-insulin antibodies.

No significant correlations were seen between IC screening tests and anti-insulin antibody levels and duration of disease, duration of insulin therapy, clinical "control". proteinuria/24 h, and beta ${ }_{2}$-microglobulinuria. The significant correlations are shown in Table 3. Statistically significant associations with higher values in two different IC screening tests were seen in patients with clinical evidence of nephropathy, pathological albuminuria, and in subjects treated with NPH insulin. Patients with peripheral vasculopathy showed significantly higher IC by PEGIgG and significantly lower IC by PEG-C4.

We also studied the correlations between groups of patients defined by clinical and biochemical data and the results of individual IC screening tests and the number of positive tests for each individual patient (Table 4). The main criteria used to define the major groups of patients in these comparisons were: (a) abnormal proteinuria; (b) evidence of microangiopathy; and (c) presence of diabetic complications. Abnormal proteinuria was defined by at least two abnormal values in the screening tests run for each urine $(24 \mathrm{~h}$ proteinuria, $24 \mathrm{~h}$ albuminuria, beta $a_{2}$-microglobulinuria, and SDS-PAGE of concentrated urine). Patients with abnormal proteinuria and/or retinopathy were considered as having evidence of microangiopathy. Finally, patients with either abnormal proteinuria, retinopathy, peripheral neuropathy, or peripheral macrovascular disease were considered as having been analysed as a whole and split into four subgroups (1) insulin-treated, (2) non-insulin-treated, (3) insulin-dependent, and (4) insulin-independent. The presence of pathological proteinuria, microangiopathy, or diabetic complications was significantly associated with the results of some individual tests for IC, particularly the PEG- 
Table 2. Results of screening tests for anti-insulin antibodies and soluble IC in insulin-treated and non-insulin-treated diabetics

\begin{tabular}{|c|c|c|c|c|}
\hline \multirow[t]{2}{*}{ Test } & \multicolumn{2}{|c|}{ Insulin-treated (95) } & \multicolumn{2}{|c|}{ Non-insulin-treated $(33)^{\mathbf{a}}$} \\
\hline & Results $^{b}$ & (\%) Positive & Results $^{\mathrm{b}}$ & (\%) Postive \\
\hline Direct nephelometry & $6.8(60)$ & 23 & $5.4(41)$ & 21 \\
\hline PEG-IgG & $0.33(0.90)$ & 26 & $0.36(0.87)$ & 33 \\
\hline PEG-C4 & $28.00 \pm 11.0$ & 30 & $28.00 \pm 11.0$ & 27 \\
\hline Clq binding & $6.2(11.5)$ & 33 & $6.6(18.3)$ & 23 \\
\hline Insulin-anti-insulin IC & $25.8(111)^{c}$ & 71 & $4.8(16)$ & 10 \\
\hline Anti-insulin antibody & $65.4(121)^{\mathrm{d}}$ & 53 & $76.4(24)$ & 7 \\
\hline
\end{tabular}

a Includes: two group I patients studied at the time of diagnosis, ten group II patients, 16 group III patients, four group IV patients, and one group $\mathrm{V}$ patient.

b Mean \pm SD for PEG-C4; mean and range for remaining tests

${ }^{c} p=0.0000$ comparing both groups by the Mann-Whitney test

${ }^{\mathrm{d}} p=0.0003$ comparing both groups by the Mann-Whitney test

Table 3. Statistical analysis of the correlations between IC screening tests, and the assay of free anti-insulin antibodies and several clinical and biochemical variables

\begin{tabular}{|c|c|c|c|c|c|c|c|}
\hline Variable & $\begin{array}{l}\text { Method of } \\
\text { statistical } \\
\text { analysis* }\end{array}$ & $\begin{array}{l}\text { Direct } \\
\text { nephelo- } \\
\text { metry }\end{array}$ & PEG-IgG & PEG-C4 & $\begin{array}{l}\text { Clq } \\
\text { binding }\end{array}$ & $\begin{array}{l}\text { Insulin- } \\
\text { anti- } \\
\text { insulin } \\
\text { IC }\end{array}$ & $\begin{array}{l}\text { Anti- } \\
\text { insulin- } \\
\text { antibodies }\end{array}$ \\
\hline Types of diabetes & $\mathrm{A}, \mathrm{B}$ & NS & NS & NS & NS & $\begin{array}{l}p=0.043^{\mathrm{b}} \\
n=148\end{array}$ & NS \\
\hline Insulin treatment & C,D & NS & NS & NS & NS & $\begin{array}{l}p=0.0000 \\
n=120\end{array}$ & $\begin{array}{l}p=0.0002 \\
n=126\end{array}$ \\
\hline Insulin dosage & $\mathrm{C}, \mathrm{D}$ & NS & $\begin{array}{l}p=0.0425 \\
n=84\end{array}$ & NS & NS & NS & NS \\
\hline Peripheral neuropathy & $\mathrm{C}, \mathrm{D}$ & NS & $\begin{array}{l}p=0.0075 \\
n=130\end{array}$ & NS & NS & NS & NS \\
\hline Nephropathy & C,D & $\begin{array}{l}p=0.022 \\
n=94\end{array}$ & $\begin{array}{l}p=0.0197 \\
n=129\end{array}$ & NS & NS & NS & $\begin{array}{l}p=0.023 \\
n=121\end{array}$ \\
\hline Retinopathy & C,D & NS & NS & NS & NS & NS & $\begin{array}{l}p=0.02 \\
n=127\end{array}$ \\
\hline $\begin{array}{l}\text { Peripheral macrovascular } \\
\text { disease }\end{array}$ & $\mathrm{C}, \mathrm{D}$ & NS & $\begin{array}{l}p=0.02 \\
n=126\end{array}$ & $\begin{array}{l}p<0.02^{\mathrm{e}} \\
n=126\end{array}$ & NS & NS & NS \\
\hline Albuminuria $(g / 24 \mathrm{~h})$ & $\mathrm{C}, \mathrm{E}$ & $\begin{array}{l}p=0.02 \\
n=55\end{array}$ & $\begin{array}{l}p=0.038 \\
n=68\end{array}$ & NS & NS & NS & NS \\
\hline SDS-PAGE of urine & $\mathrm{A}, \mathrm{B}$ & NS & NS & NS & NS & NS & $\begin{array}{l}p=0.0018^{d} \\
n=69\end{array}$ \\
\hline Type of insulin ${ }^{a}$ & $\mathrm{~A}, \mathrm{~B}$ & NS & $\begin{array}{l}p<0.05^{\mathrm{e}} \\
n=91\end{array}$ & NS & NS & $\begin{array}{l}p<0.05^{\mathrm{f}} \\
n=82\end{array}$ & NS \\
\hline
\end{tabular}

* A: analysis of variance and Duncan's multiple range test; B: Kruskal-Wallis distribution-free multiple comparison test; C: Student's t test; D: Mann-Whitney test; E: Spearman's rho test.

$\mathrm{NS}, p \geqslant 0.06$

a Patients received: (a) NPH insulin, (b) soluble insulin, or (c) NPH + soluble insulin.

b Between groups IV and I.

${ }^{c}$ Lower values in patients with peripheral vascular disease.

d Higher concentrations in patients with predominantly glomerular as compared with patients with mixed, tubular or normal proteinuria.

e Lower concentrations in patients treated with soluble or NPH + soluble insulin than in patients treated with NPH insulin only.

f Lower concentrations in patients treated soluble insulin only than in those treated with NPH or NPH + soluble insulin.

IgG test and the insulin-anti-insulin IC tests, and with the level of anti-insulin antibody, but the most consistent associations were seen in comparing the n mber of positive tests in patients with or without abnormalities.

\section{Discussion}

Diabetes mellitus has a distinctive position among immune complex diseases, since it constitutes the best example of iatrogenic production of soluble IC 
Table 4. Statistical analysis of the association between the results of IC screening techniques, the number of positive tests obtained in different patients, and the determination of anti-insulin antibody with abnormal proteinuria, evidence of microangiopathy or diabetic complications

\begin{tabular}{|c|c|c|c|c|c|c|c|c|c|}
\hline $\begin{array}{l}\text { Pathological } \\
\text { variables }\end{array}$ & $\begin{array}{l}\text { Patient } \\
\text { group }^{\mathrm{a}}\end{array}$ & $\begin{array}{l}\text { Method of } \\
\text { statistical } \\
\text { analysis }^{\mathrm{a}}\end{array}$ & $\begin{array}{l}\text { Direct } \\
\text { nephelo- } \\
\text { metry }\end{array}$ & $\begin{array}{l}\text { PEG- } \\
\text { IgG }\end{array}$ & $\begin{array}{l}\text { PEG- } \\
\text { C4 }\end{array}$ & $\begin{array}{l}\mathrm{Clq} \\
\text { binding }\end{array}$ & $\begin{array}{l}\text { Insulin } \\
\text { anti- } \\
\text { insulin } \\
\text { IC }\end{array}$ & $\begin{array}{l}\text { No. of } \\
\text { positive } \\
\text { tests }\end{array}$ & $\begin{array}{l}\text { Anti- } \\
\text { insulin } \\
\text { antibody }\end{array}$ \\
\hline \multirow[t]{3}{*}{$\begin{array}{l}\text { Abnormal } \\
\text { proteinuria }\end{array}$} & $1(33)$ & C,D & NS & $\begin{array}{l}p=0.0008 \\
n=82\end{array}$ & NS & $\begin{array}{l}\text { NS } \\
n=73\end{array}$ & $\begin{array}{l}p=0.059 \\
n=73\end{array}$ & $\begin{array}{l}p=0.001 \\
n=85\end{array}$ & $\begin{array}{l}p=0.025 \\
n=77\end{array}$ \\
\hline & $2(20)$ & $\mathrm{C}, \mathrm{D}$ & NS & $\begin{array}{l}p=0.018 \\
n=45\end{array}$ & NS & $\begin{array}{l}p=0.049 \\
n=42\end{array}$ & NS & $\begin{array}{l}p=0.008 \\
n=45\end{array}$ & NS \\
\hline & $3(13)$ & $\mathrm{C}, \mathrm{D}$ & $\begin{array}{l}p=0.049 \\
n=26\end{array}$ & NS & NS & NS & NS & NS & NS \\
\hline \multirow[t]{3}{*}{$\begin{array}{l}\text { Evidence of } \\
\text { microangiopathy }\end{array}$} & $1(42)$ & $\mathrm{C}, \mathrm{D}$ & NS & $\begin{array}{l}p=0.0174 \\
n=83\end{array}$ & NS & NS & $\begin{array}{l}p=0.0222 \\
n=83\end{array}$ & $\begin{array}{l}p=0.015 \\
n=30\end{array}$ & $\begin{array}{l}p=0.01 \\
n=87\end{array}$ \\
\hline & $2(30)$ & $\mathrm{C}, \mathrm{D}$ & $p=0.056$ & $p=0.0170$ & NS & $p=0.047$ & NS & $p=0.043$ & NS \\
\hline & $3(12)$ & $\mathrm{C}, \mathrm{D}$ & $\begin{array}{l}n=66 \\
p=0.049 \\
n=26\end{array}$ & $\begin{array}{l}n=53 \\
p=0.0435 \\
n=31\end{array}$ & NS & $\begin{array}{l}n=43 \\
\text { NS }\end{array}$ & NS & $\begin{array}{l}n=53 \\
\mathrm{NS}\end{array}$ & NS \\
\hline \multirow[t]{3}{*}{$\begin{array}{l}\text { Diabetic } \\
\text { complications }\end{array}$} & $1(46)$ & C,D & $\begin{array}{l}p=0.056 \\
n=74\end{array}$ & $\begin{array}{l}p=0.0055 \\
n=91\end{array}$ & NS & NS & $\begin{array}{l}p=0.0301 \\
n=83\end{array}$ & $\begin{array}{l}p=0.002 \\
n=89\end{array}$ & $\begin{array}{l}p=0.015 \\
n=87\end{array}$ \\
\hline & $2(34)$ & $\mathrm{C}, \mathrm{D}$ & NS & $\begin{array}{l}p=0.0099 \\
n=56\end{array}$ & NS & $\begin{array}{l}p=0.035 \\
n=46\end{array}$ & NS & $\begin{array}{l}p=0.025 \\
n=56\end{array}$ & NS \\
\hline & $3(15)$ & $\mathrm{C}, \mathrm{D}$ & NS & NS & NS & NS & NS & $\begin{array}{l}p=0.033 \\
n=30\end{array}$ & NS \\
\hline
\end{tabular}

a Patient groups: 1, whole group; 2, insulin-treated patient; 3, non-insulin-treated patients. The number of patients with abnormalities is given in parentheses.

NS, $p \geq 0.06$

as the result of prolonged administration of an immunogenic heterologous protein. The existence of soluble insulin-anti-insulin IC, first documented by Jayarao et al. [15], was confirmed by us by isolating insulin-anti-insulin IC from the serum of an insulintreated diabetic [16]. Our results show that such IC can be detected in $71 \%$ of 95 insulin-treated patients from a random series in which only three patients had insulin resistance (as defined by requirement of over $200 \mathrm{U} /$ day of insulin), while only three out of 33 non-insulin-treated diabetics showed low positive results (two of them at $10 \%$, the cut-off of positivity being $9 \%$ ) in the test for detection of insulin-antiinsulin IC.

It seems unquestionable that insulin-anti-insulin IC arise primarily as a consequence of insulin therapy, and the possible different antigenicity of different types of insulin, previously suggested in the literature $[1,20]$, is also supported by our study. A significant association between insulin type and IC levels was found with the PEG-IgG test and the insulin-anti-insulin IC test showing that NPH insulin was significantly associated to higher IC levels than soluble insulin. On the other hand, anti-insulin antibody levels were strongly associated with insulin therapy, but their levels were not related to the dosage of insulin or with the duration of insulin therapy. This lack of association between the immune response and immunisation factors, such as the antigen dosage and length of immunisation, suggests that perhaps genetic factors have a strong influence in determining the magnitude of the immune response. This is supported by the finding of associations between certain HLA phenotypes and high or low anti-insulin antibody levels $[14,27]$.

If no doubts remain about the existence and iatrogenic origin of insulin-anti-insulin IC in a large majority of insulin-treated patients, the pathogenic significance of such IC remains questionable. A pathogenic role for insulin-anti-insulin IC is supported by the finding of significant associations between abnormal proteinuria, evidence of microangiopathy, and presence of diabetic complications with higher values in the Clq binding test and the PEGIgG test in insulin-treated patients, while in noninsulin-treated patients we found a significant association only between microangiopathy and the PEGIgG test. However, the lack of significant associations 
between complications and insulin-anti-insulin IC in insulin-treated patients contradicts that impression. The statistical analysis also provides a puzzling result in the consistent association between insulin-antiinsulin IC and the presence of abnormal proteinuria, microangiopathy, or diabetic complications in general in insulin-independent patients. However, it should be pointed out that the highest rate of diabetic complications was seen in insulin-treated, insulinindependent patients. Such patients were placed on insulin therapy when difficult to control with oral antidiabetic agents and diet, so the possibility exists that the complications might have existed before insulin therapy. When the correlation between insulin-anti-insulin IC, nephropathy, microangiopathy, and complications in insulin independent patients was re-examined, excluding non-insulin-treated individuals, no significant differences were seen between patients with and without abnormalities.

The presence of IC other than insulin-anti-insulin in diabetics has been suggested by several authors [ 4 , $11,18]$, and is supported by the practically identical positivity ratios in the nonspecific IC screening tests between insulin-treated and non-insulin-treated patients. This is an important argument for the use of both specific and nonspecific IC screening tests; and in general, all IC screening tests showed higher values in patients with clinical and biochemical abnormalities, but statistical significance was reached in only $30 \%$ of the comparisons, with a markedly higher rate of association with the results of the PEG-IgG test. The general trend of the results was best expressed by the number of positive tests in each patient, with the number of significant associations in the comparisons increasing to $66 \%$ when the number was used for statistical comparisons. This seems to suggest that the input from multiple tests can help in better defining the differences between patient populations with regard to the presence or absence of circulating IC, since different tests often show discrepant results, perhaps detecting IC with different characteristics $[7-9,23,29,30]$.

Taken as a whole, our results point towards an association between high levels of soluble IC and the presence of complications, such as peripheral neuropathy, nephropathy, and retinopathy. Such associations appear to be easier to elicit when sensitive techniques are used to detect early damage, as illustrated with the studies of abnormal proteinuria. Whether or not soluble IC are a major pathogenic factor for the development of diabetic microangiopathy and other complications cannot be proven by our studies. If, however, we consider the strong statistical associations found in this study, particularly in the case of abnormal proteinuria, with the known capacity of soluble IC to induce glomerular disease, it seems possible that soluble IC may at least be one of several factors contributing to the development of glomerular damage. If this postulate is accepted, its logical implication will be the need to minimise the antigenicity of insulin, either by using less immunogenic insulins or by using routes of administration less likely to result in antibody production. The lesser antigenicity of highly purified porcine insulin has been well documented $[1,24]$, and it seems likely that the use of highly purified insulin administered through continuous perfusion devices might significantly decrease immune reactions to insulin.

Acknowledgments. We wish to acknowledge the excellent technical assistance of Ms. Mary D. Adams, Ms. Deborah Russell, Ms. Marta Laimins, and Ms. Gracie Evans. The cooperation of the nurses and personnel of the Specialized Diagnostic and Therapeutic Unit at the Charleston Veterans Administration Medical Center is greatly appreciated. Mr. Charles L. Smith provided excellent editorial assistance.

Publication no. 434 from the Department of Basic and Clinical Immunology and Microbiology, Medical University of South Carolina. Research supported in part by the Kroc Foundation, by the Veterans Administration, and by South Carolina State Appropriations for Biomedical Research, 1978-79 and 1979-80. Dr. Lopes-Virella is the recipient of a Special Emphasis Research Career Award (SERCA) from the NHLBI-NIAMDD, National Institutes of Health.

\section{References}

1. Asplin CM, Hartog M, Goldie DJ (1978) Change of insulin dosage, circulating free and bound insulin and insulin antibodies on transfering diabetics from conventional to highly purified porcine insulin. Diabetologia 14: 99-105

2. Colwell AR (1977) Diabetes mellitus in general practice. Yearbook Publishers, Chicago, Illinois, p 111

3. Deaton CD, Maxwell KW, Smith RS, Creveling RL (1976) Use of laser nephelometry in the measurement of serum proteins. Clin Chem 22: 1465-1471

4. Delespesse G, Gausset Ph, Sarfati M, Dubi-Rucquoy M, Debisschop MJ, van Haelst L (1980) Circulating immune complexes in old people and in diabetics: Correlation with autoantibodies. Clin Exp Immunol 40: 96-102

5. Digeon M, Laver M, Riza J, Bach JF (1977) Detection of circulating immune complexes in human sera by simplified assays with polyethylene glycol. $J$ Immunol Methods 16 : 165-183

6. Faulk WP, Karam J, Fudenberg HH (1971) Human anti-insulin antibodies. J Immunol 106: 1112-1116

7. Gupta RC, McDuffie FC, Huston KA, Tappeniner G, Meurer M, Jordona RE, Luthra HS, Hunder GG, Ilstrup D (1979) Comparison of three immunoassays for immune complexes in rheumatoid arthritis. Arthritis Rheum 22: 433-439

8. Halla JT, Volanakis JE, Schrohenloher RE (1979) Circulating immune complexes in mixed connective tissue disease. Arthritis Rheum 22: 484-489

9. Hardin JA, Walker LC, Steere AC, Trumble TC, Tung KSK, Williams RC, Ruddy S, Malawista SE (1979) Circulating 
immune complexes in Lyme arthritis. Detection by the ${ }^{125} \mathrm{I}$ Clq binding, Clq solid phase, and Raji cell assays. $\mathrm{J}$ Clin Invest 63: $468-477$

10. Herbert V. Liu K-S. Gottlieb CW, Bleicher SJ (1965) Coated charcoal immunoassay of insulin. J Clin Endocrinol Metab 25: 1375-1384

11. Irvine WJ, Al-Khateeb SF, DiMario U, Feek CM, Gray RS, Edmond B, Duncan LJR (1977) Soluble immune complexes in the sera of newly diagnosed insulin-dependent diabetics and in treated diabetics. Clin Exp Immunol 30: 16-21

12. Irvine WJ, DiMario V, Guy K, Feek CM, Gray RS, Duncan LJP (1978) Immune complexes in newly diagnosed insulindependent (Type I) diabetics. J Clin Immunol 1: 183-186

13. Irvine WJ, DiMario U, Guy K, Iavicoli M, Pozzilli P, Lumbroso B, Andrani D (1978) Immune complexes and diabetic microangiopathy. J Clin Lab Immunol 1: 187-191

14. Irvine WJ, DiMario U, Feek CM, Ting A, Morris PJ, Gray RS and Duncan LJP (1978) Insulin antibodies in relation to islet cell antibodies and HLA antigens in insulin dependent (Type I) diabetes. J Clin Lab Immunol 1: 111-114

15. Jayarao KS, Faulk WP, Karam JH, Grodsky GM, Forsham PH (1973) Measurement of immune complexes in insulin-treated diabetics. J Immunol Methods 3: 337-346

16. Kilpatrick JM, Virella G (1980) Isolation and characterization of in vitro and in vivo formed soluble insulin-anti-insulin immune complexes in sera from patients with diabetes mellitus. Clin Exp Immunol 40: 445-452

17. Kumar D, Quismorio FP (1978) Circulating immune complexes in diabetic patients. Diabetes 27: 486

18. Kumar D, Zeidler A, Quismorio FP (1979) Circulating immune complexes, islet cell and insulin antibodies. Diabetes 28: 378

19. Lambert PH, Dixon FJ, Zubler RH, Agnello V, Cambiaso C, Casali P, Clarke J, Cowdery JS, McDuffie FC, Hay FC, MacLennan ICM, Masson P, Muller-Eberhard HJ, Penttinen K, Smith Tappeiner G, Theofilopoulos AN, Verroust P (1978) A WHO collaborative study. J Clin Lab Immunol 1: 1-15

20. Little JA, Lee R, Sebrizkova N, Csima A (1977) Insulin antibodies and clinical complications in diabetics treated for five years with lente or sulfonated insulin. Diabetes 26: 980-988

21. Lopes-Virella MF, Virella G, Rosebrock G, Sagel J, Gonzalez J, Colwell J (1979) Early diagnosis of renal malfunction in diabetics. Abnormal proteinuria revealed by sodium dodecyl sulphate-polyacrylamide gel electrophoresis. Diabetologia 16: 165-171

22. Mainland D (1963) Elementary Medical Statistics, 2nd edn. Saunders, Philadelphia, pp 241-269

23. Milgrom F, Kano K (1978) Comparison of various procedures for the detection of antigen-antibody complexes. Int Arch Allergy Appl Immunol 56: 224-231

24. Mustaffa BE, Daggett PR, Nabarro JDN (1977) Insulin binding capacity in patients changed from conventional to highly purified insulins. Diabetologia 13: $311-315$

25. Pires MT, da Cunha AS, Virella G, Simoes J (1975) Analytical characterization of urinary proteins by sodium dodecyl sulphate polyacrylamide gel electrophoresis in renal disease. Nephron 14: 361-372

26. Schernthaner G, Ludwig H, Tappeiner G, Mayr WR (1979) Circulating immune complexes, IgG-insulin antibodies, islet cell antibodies and HLA antigens in insulin-dependent diabetics. Diabetes 28: 378

27. Schernthaner G, Ludwig H, Mayr WR (1979) Immunoglobulin G-insulin antibodies and immune region-associated alloantigens in insulin-dependent diabetes mellitus. J Clin Endocrinol Metab 48: 403-407

28. Spicer KM, Allen RC, Buse MG (1978) A simplified assay of hemaglobin $\mathrm{A}_{1 \mathrm{c}}$ in diabetic patients using isoelectric focusing and quantitative microdensitometry. Diabetes 27 : 384-388

29. Tung KSK, Kim B, Kronvall BG, McLaren LC, Williams RC (1977) Discrepancy between Clq deviation and Raji cell tests in detection of circulating immune complexes in patients with leprosy. J Infect Dis 136: 216-221

30. Tung KSK, Woodroffe AJ, Ahlin TD, Williams RC, Wilson CB (1978) Application of the solid phase Clq and Raji cell radioimmunossays for the detection of circulating immune complexes in glomerulonephritis. J Clin Invest 61: 61-72

31. Virella G, Hipp WA, John JF, Kahaleh B, Ford M, Fudenberg $\mathrm{HH}$ (1979) Nephelometric detection of soluble immune complexes: Methodology and clinical applications. Int Arch Allergy Appl Immunol 58: 402-410

32. Virella G, Russell D, Laimins M, Colwell J (1980) Simplified method for detecting anti-insulin antibodies and insulin-antiinsulin immune complexes. Clin Chem 26: 1357-1359

33. Zubler RH, Lange GT, Lambert PH, Miescher PA (1976) Detection of immune complexes in unheated sera by a modified ${ }^{125} \mathrm{I}-\mathrm{Clq}$ binding test. J Immunol 116: $232-235$

Received: 19 September 1980

and in revised form: 6 April 1981

Dr. G. Virella

Department of Basic \& Clinical Immunology

Medical University of South Carolina

171 Ashley Avenue

Charleston, SC 29403, USA 